\title{
Increased Expression of Insulin/Insulin-like Growth Factor-I Hybrid Receptors in Skeletal Muscle of Noninsulin-dependent Diabetes Mellitus Subjects
}

\author{
Massimo Federici, ${ }^{\star}$ Luigi Zucaro, ${ }^{\star}$ Ottavia Porzio, ${ }^{\star}$ Renato Massoud, $¥ \S$ Patrizia Borboni, ${ }^{\star}$ Davide Lauro, ${ }^{\star}$ and Giorgio Sesti ${ }^{\star}$ \\ *Department of Internal Medicine, University of Rome, Tor Vergata, Rome, Italy; ${ }^{\star}$ Clinical Biochemistry Unit, University of Rome, Tor \\ Vergata, Rome, Italy; and \$Bambino Gesù Pediatric Hospital, Rome, Italy
}

\begin{abstract}
Insulin receptors (IR) and IGF-I receptors (IGF-IR) have been shown to form hybrid receptors in tissues coexpressing both molecules. To date there is no information about the distribution of hybrids in tissues of normal or diabetic subjects. We developed a microwell-based immunoassay to quantitate hybrids in small human tissues samples. Microwells were coated with MA-20 anti-IR antibody or $\alpha$-IGFIR-PA antibody directed against the IGF-IR $\alpha$-subunit, and incubated with skeletal muscle extracts of patients with noninsulin-dependent diabetes mellitus (NIDDM) and normal controls. Immobilized receptors were incubated with ${ }^{125}$ I-insulin or ${ }^{125} \mathrm{I}-\mathrm{IGF}-\mathrm{I}$ in the presence or absence of the two unlabeled ligands. Hybrids were quantified as the fraction of ${ }^{125}$ I-IGF-I binding immunoadsorbed with MA-20 and expressed as percentage of total IGF-IR (type I+hybrids) immobilized with $\alpha$-IGF-IR-PA. The immunoassay was validated using Western blotting analysis. Relative abundance of hybrids detected in NIDDM patients was higher than in controls. The percentage of hybrids was negatively correlated with IR number and in vivo insulin sensitivity measured by an insulin tolerance test, whereas the percentage was positively correlated with insulinemia. Insulin binding affinity was lower in NIDDM patients than in controls, and was correlated with the percentage of hybrids. Maximal IGF-I binding was significantly higher in muscle from NIDDM patients compared to controls and was positively correlated with the percentage of hybrid receptors whereas IGF-I binding affinity did not differ between the two groups. These results raise the possibility that alterations in expression of hybrid receptors may contribute to decreased insulin sensitivity, and to increased sensitivity to IGF-I. Because IGF-I has been proposed as a hypoglycemic agent in NIDDM, these results are relevant to the development of new approaches to the treatment of insulin resistance of NIDDM. (J. Clin. Invest. 1996. 98:2887-2893.) Key words: insulin receptor $\bullet$ IGF-I receptor $\bullet$ hybrid receptor $\bullet$ insulin resistance
\end{abstract}

Address correspondence to Giorgio Sesti, M.D., Dipartimento di Medicina Interna, Università di Roma-Tor Vergata, Via Orazio Raimondo, 00173 Roma, Italy. Phone: 39-6-72596528; FAX: 39-672596538; E-mail: SESTI@UTOVRM.IT

Received for publication 23 July 1996 and accepted in revised form 15 October 1996.

J. Clin. Invest.

(C) The American Society for Clinical Investigation, Inc.

0021-9738/96/12/2887/07 \$2.00

Volume 98, Number 12, December 1996, 2887-2893

\section{Introduction}

The pathophysiology of noninsulin-dependent diabetes mellitus (NIDDM) ${ }^{1}$ involves defects in both insulin secretion and peripheral insulin action (1). Skeletal muscle is a major site of insulin-stimulated glucose disposal and has been suggested to be the primary tissue responsible for insulin resistance in the postabsorptive state (2). Insulin action is initiated through hormone binding to cell surface receptors which triggers a cascade of intracellular phosphorylation events (3). The insulin receptor is a glycoprotein which shares structural and functional homology with the insulin-like growth factor (IGF-I) receptor (4-6). Both receptors are composed of two $\alpha$-subunits linked to $\beta$-subunits and to each other by disulfide bonds and noncovalent interactions. The $\alpha$ - and $\beta$-subunits are synthesized as a single-chain proreceptor which is glycosylated and proteolytically cleaved to yield the mature $\alpha 2 \beta 2$ heterotetrameric receptor. The $\alpha$-subunits are entirely extracellular and contain the hormone binding site(s), while the membrane-spanning $\beta$-subunits possess the intrinsic tyrosine kinase activity in their cytoplasmic domain. Several lines of evidence have suggested that hybrid receptors composed of an insulin receptor $\alpha \beta$-heterodimer and an IGF-I $\alpha \beta$-heterodimer are formed in tissues coexpressing the two receptors $(7,8)$. Hybrid receptors were first identified by studies demonstrating high affinity IGF-I binding immunoreactive with insulin receptor-specific antibodies (7). The formation of hybrid receptors was subsequently shown in a variety of transfected rodent cells overexpressing insulin or IGF-I receptors by examining their reactivity with species- and receptor-specific antibodies (9). Assembly of insulin/IGF-I hybrid receptors was also demonstrated in vitro under defined ligand incubation conditions (10). The functional significance of these hybrid receptors is still undefined. Previous studies have shown that insulin/IGF-I hybrid receptors bind IGF-I with an affinity similar to that seen with type I IGF receptors, but bind insulin with lower affinity than classic insulin receptors $(11,12)$. Furthermore, hybrid receptors function more like an IGF-I receptor rather than an insulin receptor with respect to receptor autophosphorylation, and IGF-I internalization and degradation (12-14). Therefore, an increased proportion of insulin/IGF-I hybrid receptors would be expected to reduce insulin binding, and, thereby, insulin sensitivity in tissues expressing both receptors. Based on these observations, we asked the question of whether increased expression of insulin/IGF-I hybrid receptors might contribute, at least in part, to the insulin resistance of NIDDM. To this end, we have measured the abundance of insulin/IGF-I hybrid re-

1. Abbreviations used in this paper: IGF-IR, IGF-I receptors; IR, insulin receptors; NIDDM, noninsulin-dependent diabetes mellitus; PA, polyclonal antibody; rhIGF-I, recombinant human IGF-I. 
ceptors in skeletal muscle from normal and NIDDM subjects using a microwell-based immunoassay and correlated hybrid receptors expression with in vivo insulin sensitivity.

\section{Methods}

Materials. Tissue samples of subcutaneous rectus abdominus skeletal muscle were obtained during elective abdominal surgery from eight nonobese normal subjects and eight NIDDM patients admitted to the hospital for cholecystectomy or total hysterectomy. Tissue samples were cleaned of all connective tissue and blood, immediately frozen in liquid nitrogen, and stored at $-70^{\circ} \mathrm{C}$ until use. Clinical and biochemical data of the subjects are shown in Table I. The control subjects had normal fasting plasma glucose levels, normal blood pressure, and no family history of diabetes. All NIDDM patients were diagnosed according to the criteria of the National Diabetes Data Group (15), and were treated with diet alone. No subject had taken any other medication known to alter insulin or glucose metabolism. Insulin sensitivity was assessed by i.v. insulin tolerance test (ITT), performed as previously described (16). After an overnight fast, a single bolus of regular insulin $(0.1 \mathrm{U} / \mathrm{kg}$ body wt i.v.) was injected into an antecubital vein. Blood samples were collected at 15 and 5 min before and $3,6,9,12,15,20$, and $30 \mathrm{~min}$ after insulin injection. Glucose was injected at the end of ITT to stop the fall in plasma glucose. The constant rate for plasma glucose disappereance $\left(\mathrm{K}_{\mathrm{itt}}\right)$ was calculated according to the formula $0.693 / t_{1 / 2}$. The plasma glucose $t_{1 / 2}$ was calculated from the slope of least square analysis of the plasma glucose concentrations from 3-15 min after intravenous insulin injection, when the plasma glucose concentration declined linearly. Consent was obtained from all subjects after the nature of the procedure was explained. The study was performed in accordance with the principles of the Declaration of Helsinki.

A polyclonal antibody ( $\alpha$-IGF-I receptor $[\mathrm{R}]-\mathrm{PA})$ was raised in rabbit against a synthetic peptide corresponding to residues 642-661 of the IGF-I receptor $\alpha$-subunit sequence (6), according to previously described method (17). MA-20 monoclonal antibody to the insulin receptor was produced as previously described (18).

Human ${ }^{125} \mathrm{I}-\mathrm{A} 14-$ monoiodoinsulin $(290-320 \mu \mathrm{Ci} / \mu \mathrm{g})$ was a gift from Dr. Luca Benzi (University of Pisa, Pisa, Italy) (19). ${ }^{125}$ I-IGF-I (280-310 $\mu \mathrm{Ci} / \mu \mathrm{g})$ was purchased from DuPont-New England $\mathrm{Nu}-$ clear (Wilmington, DE). Human recombinant insulin was graciously provided by Novo-Nordisk A/S (Bagsværd, Denmark). Human recombinant IGF-I was obtained from Boehringer Mannheim Biochemica (Mannheim, Germany). All other chemicals were from Sigma Chemicals Co. (St. Louis, MO).

Tissue solubilization. Extracts from skeletal muscle were prepared by solubilization in $50 \mathrm{mM}$ Hepes buffer, $\mathrm{pH}$ 7.6, containing $150 \mathrm{mM} \mathrm{NaCl}, 1 \%$ Triton X-100, $1 \mathrm{mg} / \mathrm{ml}$ bacitracin, $2 \mathrm{mM}$ PMSF, $1000 \mathrm{U} / \mathrm{ml}$ aprotinin for $60 \mathrm{~min}$ at $4^{\circ} \mathrm{C}$, and insoluble material was removed by centrifugation at $100,000 \times g$ for $60 \mathrm{~min}$ at $4^{\circ} \mathrm{C}$. Soluble fractions were diluted to $0.2 \%$ Triton $\mathrm{X}-100$ and immediately assayed. Protein content of tissue extracts was determined by the Bradford method (20).

Table I. Clinical Characteristics of Study Subjects

\begin{tabular}{lcc}
\hline & Normal & NIDDM \\
\hline Sex $(\mathrm{M} / \mathrm{F})$ & $3 / 5$ & $4 / 4$ \\
Age $(\mathrm{yr})$ & $50 \pm 6$ & $61 \pm 4$ \\
BMI $\left(\mathrm{kg} / \mathrm{m}^{2}\right)$ & $25.9 \pm 1$ & $26.2 \pm 1$ \\
Fasting glucose $(\mathrm{mmol} / \mathrm{liter})$ & $3.6 \pm 0.7$ & $4.2 \pm 0.8$ \\
Fasting insulin $(\mu \mathrm{U} / \mathrm{ml})$ & $6.0 \pm 2.4^{*}$ & $10.2 \pm 3.0^{*}$ \\
Insulin tolerance $\left(\mathrm{K}_{\text {itt }}\right)$ & $3.9 \pm 0.6^{\ddagger}$ & $1.8 \pm 0.6^{\ddagger}$ \\
& &
\end{tabular}

$* P<0.0012 ;{ }^{\ddagger} P<0.0001$.
Microwell immunoassay. 96-well microwells were coated with 50 $\mu \mathrm{l}$ of $\alpha$-IGF-IR-PA or MA-20 antibody (both $10 \mu \mathrm{g} / \mathrm{ml}$ ) in $20 \mathrm{mM}$ $\mathrm{NaHCO}_{3}, \mathrm{pH} 9.6$, and incubated for $16 \mathrm{~h}$ at $4^{\circ} \mathrm{C}$. The wells were washed three times with binding buffer containing $50 \mathrm{mM}$ Hepes buffer, $\mathrm{pH}$ 7.6, $150 \mathrm{mM} \mathrm{NaCl}, 0.1 \%$ Triton $\mathrm{X}-100,1 \mathrm{mg} / \mathrm{ml}$ bacitracin, $2 \mathrm{mM}$ PMSF, $1,000 \mathrm{U} / \mathrm{ml}$ aprotinin, $0.1 \% \mathrm{BSA}$, and incubated with tissue extracts $(500 \mu \mathrm{g}$ in $40 \mu \mathrm{l})$ for $16 \mathrm{~h}$ at $4^{\circ} \mathrm{C}$. The wells were then washed three times with binding buffer, and immobilized receptors were incubated in the same buffer with ${ }^{125}$ I-IGF-I $(60 \mathrm{pM})$ or ${ }^{125} \mathrm{I}$-insulin $(60 \mathrm{pM})$ for $16 \mathrm{~h}$ at $4^{\circ} \mathrm{C}$ in the presence or absence of various concentrations of the corresponding unlabeled ligands. Thereafter, the wells were washed three times with binding buffer to remove unbound ligands. Radioactivity bound to immobilized receptors was collected by adding $2 \%$ SDS for $30 \mathrm{~min}$ at $24^{\circ} \mathrm{C}$ to the wells, and counted in a gamma counter.

Insulin and IGF-I binding data were analyzed by the method of Scatchard (21) using the LIGAND computer program.

Western blotting. Equal amount of tissue extracts $(500 \mu \mathrm{g})$ were incubated for $16 \mathrm{~h}$ at $4^{\circ} \mathrm{C}$ with $1 \mu \mathrm{g}$ of either $\alpha$-IGF-IR-PA or MA-20 antibody each bound to Protein A-Sepharose. The immunoprecipitates were subjected to sodium dodecyl sulfate-polyacrylamide gel electrophoresis (SDS-PAGE) under reducing conditions. Proteins (500 $\mu \mathrm{g} /$ lane) resolved by SDS-PAGE were electrophoretically transferred to nitrocellulose filters. The nonspecific binding sites of membranes were blocked by a 2-h incubation of Tris-buffered saline (TBS, $\mathrm{pH} 7.5)$ containing $5 \%$ BSA. The filters were then incubated for $16 \mathrm{~h}$ at $4^{\circ} \mathrm{C}$ with affinity-purified $\alpha$-IGF-IR-PA antipeptide antibody (1:100 dilution). After extensive washings with TBS, the bound antibody was detected with alkaline phosphatase-conjugated anti-rabbit immunoglobulins. Band densities were quantified by bidimensional densitometry using a scanning densitometer (model GS670; Bio-Rad Laboratories, Richmond, CA).

Statistical analysis. Unpaired Student's $t$ test was used to compare mean values. Linear correlations between variables were tested by calculating Pearson's correlation coefficient.

\section{Results}

Characterization of microwell-based immunoassay. To measure insulin and IGF-I binding to receptors and quantitate the abundance of insulin/IGF-I hybrid receptors, receptors were immunoadsorbed on a microwell plate using MA-20, an antiinsulin receptor monoclonal antibody that does not cross-react with IGF-I receptors or $\alpha$-IGF-IR-PA, an anti-IGF-I receptor polyclonal antibody that does not cross-react with insulin receptors $(18,22)$. Microwells coated with either MA-20 or $\alpha$-IGF-IR-PA antibody were incubated with muscle extracts, and ligand binding characteristics of immobilized receptors were examined by competition-inhibition binding studies. Binding of insulin and IGF-I to their own receptors isolated from muscle extracts was similar to that obtained by immunoprecipitation of solubilized receptors. Furthermore, the immunoassay with either antibody was quantitative since both $\alpha$-IGF-IR-PA and MA-20 were able to remove $>92 \%$ of their respective receptors in immunodepletion experiments.

Ligand binding studies in skeletal muscle of normal and NIDDM subjects. Tissue extracts were prepared from muscle samples of NIDDM patients and normal subjects ( $n=8$ each) and added to microwell coated with MA-20 or $\alpha$-IGF-IR-PA antibody. After washing, ligand binding to immobilized receptors was assessed by incubating the wells with ${ }^{125}$ I-labeled insulin or IGF-I in the presence or absence of varying concentrations of unlabeled ligand. Maximal insulin binding to MA20-immobilized receptors was significantly lower in muscle from NIDDM patients compared to normal individuals $(\mathrm{B} / \mathrm{T}=$ 

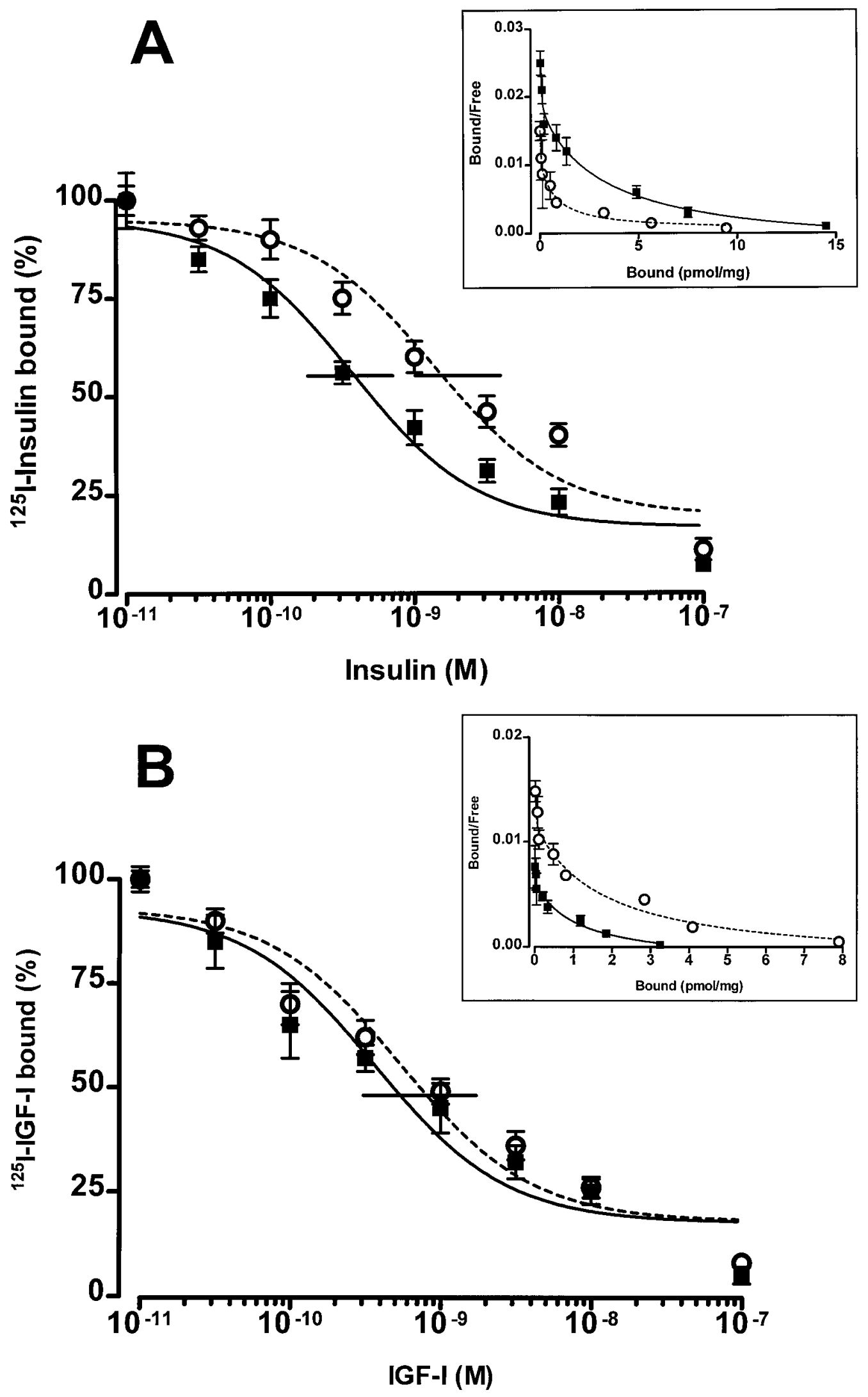

Figure 1. Inhibition of ${ }^{125} \mathrm{I}-$ insulin or ${ }^{125}$ I-IGF-I binding to immobilized receptors. Tissue extracts prepared from skeletal muscle of eight NIDDM patients (open circles) and eight normal subjects (closed squares) were used to measure insulin (inset; $A$ ) or IGF-I (inset; $B$ ) binding to immobilized receptors as described in Methods. Results of insulin $(A)$ or IGF-I $(B)$ binding competition expressed as percent of maximal binding are presented as mean \pm SEM. Scatchard plots of insulin (inset, $A$ ) and IGF-I (inset, $B$ ) binding data.

$1.40 \pm 0.2$ and $3.02 \pm 0.5 ; P<0.003$, respectively). The mean values for total ${ }^{125} \mathrm{I}$-insulin binding were $6,040 \pm 1,200 \mathrm{cpm} / \mathrm{mg}$ protein for normal subjects vs. 2,800 $\pm 420 \mathrm{cpm} / \mathrm{mg}$ for NIDDM patients. Binding inhibition curves for the two groups of sub- jects are shown in Fig. 1. Receptor binding affinity, estimated as the concentration of unlabeled insulin required to inhibit $50 \%$ of maximal ${ }^{125}$ I-insulin binding to MA-20-immobilized receptors $\left(\mathrm{IC}_{50}\right)$, was significantly decreased in muscle from 
NIDDM patients compared to normal subjects $\left(\mathrm{IC}_{50}=\right.$ $1.29 \pm 0.13$ and $0.47 \pm 0.1 \mathrm{nM} ; P<0.007$, respectively). Scatchard analysis of insulin binding data showed that the number and affinity of the binding sites were reduced in NIDDM patients compared to normal subjects $(\mathrm{Ro}=14.5 \pm 1.2 \mathrm{pmol} / \mathrm{mg}$ protein; $K_{d}=0.13 \pm 0.01 \mathrm{nM}$ and $R o=9.44 \pm 0.9 \mathrm{pmol} / \mathrm{mg}$ protein; $\mathrm{K}_{\mathrm{d}}=0.52 \pm 0.02 \mathrm{nM}$ for normal subjects and NIDDM patients, respectively) (inset, Fig. $1 A$ ). The number of insulin receptors was inversely correlated with fasting insulin levels $(r=-0.60 ; P<0.02)$. Maximal IGF-I binding to $\alpha$-IGF-IRPA-immobilized receptors was significantly higher in muscle from NIDDM patients compared to normal individuals $(\mathrm{B} / \mathrm{T}=$ $1.8 \pm 0.36$ and $0.85 \pm 0.27 ; P<0.05$, respectively). The mean values for total ${ }^{125}$ I-IGF-I binding were $1,900 \pm 440 \mathrm{cpm} / \mathrm{mg}$ protein for NIDDM patients versus $800 \pm 170 \mathrm{cpm} / \mathrm{mg}$ for normal subjects. As shown in Fig. 1, receptor binding affinity was similar in the two groups of subjects $\left(\mathrm{IC}_{50}=0.36 \pm 0.1\right.$ and $0.44 \pm 0.09 \mathrm{nM}$, respectively, in NIDDM patients and normal subjects). Scatchard analysis of IGF-I binding data revealed that an increased number of binding sites in NIDDM patients compared to normal subjects $(\mathrm{Ro}=7.9 \pm 0.7 \mathrm{pmol} / \mathrm{mg}$ protein and $\mathrm{Ro}=3.25 \pm 0.3 \mathrm{pmol} / \mathrm{mg}$ protein, respectively) whereas binding affinity was similar in the two groups $\left(\mathrm{K}_{\mathrm{d}}=0.6 \pm 0.2\right.$ $\mathrm{nM}$ and $0.9 \pm 0.2 \mathrm{nM}$ for NIDDM patients and normal subjects, respectively) (inset, Fig. $1 B$ ).

Quantitation of insulin/IGF-I hybrid receptors in skeletal muscle of normal and NIDDM subjects. The assay of insulin/ IGF-I hybrid receptors was based on their ability to bind IGF-I, but not for insulin, with high affinity, and to react with specific antiinsulin receptor antibody $(7,9,11)$. Tissue extracts ob-

\section{BLOT: ANTI-IGF-I R $\alpha$ SUBUNIT}

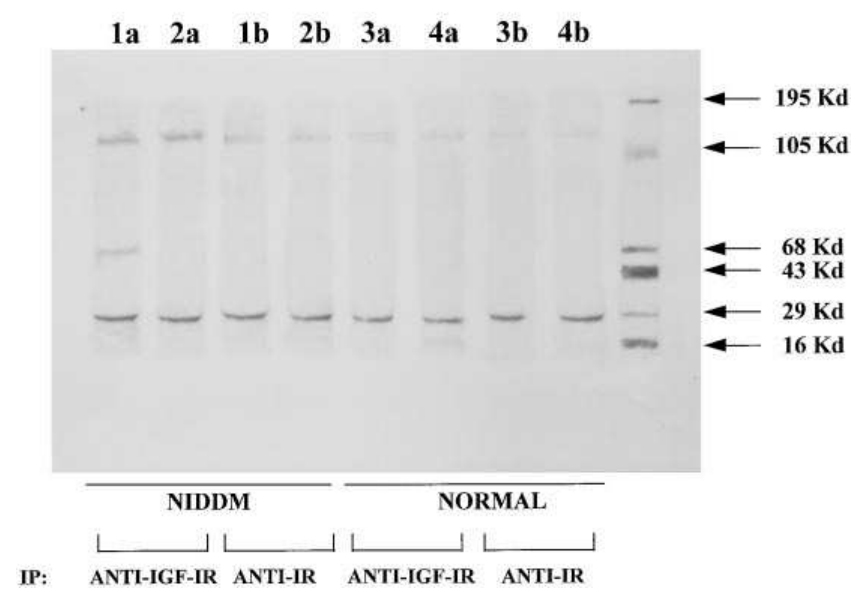

Figure 3. Quantitation of insulin/IGF-I hybrid receptors by Western blotting. Equal amount of tissue extracts $(500 \mu \mathrm{g})$ prepared from skeletal muscle of two NIDDM patients (lanes 1 and 2) and two normal subjects (lanes 3 and 4 ) were precipitated with $\alpha$-IGF-IR-PA or MA-20 antibody. The immunoprecipitates were subjected to SDSPAGE under reducing conditions. Proteins resolved by SDS-PAGE were electrophoretically transferred to nitrocellulose filters. The filters were incubated with affinity-purified $\alpha$-IGF-IR-PA antibody (1:100 dilution), and the bound antibody was detected with alkaline phosphatase-conjugated anti-rabbit immunoglobulins. Band densities were quantified by scanning densitometry. The intensities expressed as arbitrary densitometric units were: 3.42 (lane $1 a$ ), 3.32 (lane $2 a$ ), 2.51 (lane $1 b$ ), 2.09 (lane 2 b), 1.28 (lane $3 a$ ), 1.04 (lane $4 a), 0.53$ (lane $3 b$ ), and 0.45 (lane $4 b$ ).

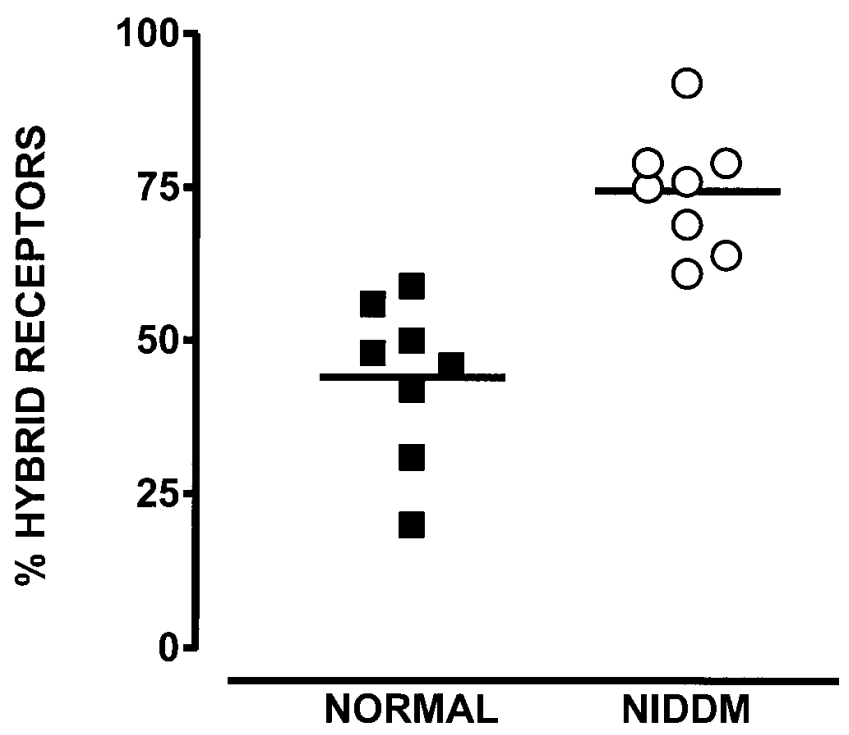

Figure 2. Quantitation of insulin/IGF-I hybrid receptors in skeletal muscle of normal and NIDDM subjects. Tissue extracts were added to microwell coated with MA-20 or $\alpha$-IGF-IR-PA antibody, and immobilized receptors were then incubated with ${ }^{125}$ I-IGF-I $(60 \mathrm{pM})$ in the presence or absence of unlabeled IGF-I (100 nM). Hybrid receptors were estimated as the percentage of ${ }^{125}$ I-IGF-I binding sites reactive with MA-20 antibody vs. total of ${ }^{125}$ I-IGF-I binding sites (hybrids + type I receptors) reactive with $\alpha-$ IGF-IR-PA antibody. Each point represents the mean value for a single subject measured in three experiments each in triplicate. The mean for the two groups of subjects is shown as a horizontal bar. tained from skeletal muscle of NIDDM patients and normal subjects ( $n=8$ each) were added to microwell coated with MA-20 antiinsulin receptor antibody. MA-20-immobilized receptors were then incubated with ${ }^{125}$ I-IGF-I (60 pM) in the presence or absence of increasing amounts of unlabeled IGF-I and hybrid receptors were estimated as the fraction of ${ }^{125}$ I-IGF-I binding immunoadsorbed with MA-20 antibody vs. total of ${ }^{125}$ I-IGF-I binding sites (hybrids + type I receptors) immunoadsorbed with $\alpha$-IGF-IR-PA antibody. Under these conditions, no significant ${ }^{125}$ I-IGF-I binding to insulin receptors was detected, as deduced by the inability of low concentration of unlabeled insulin to compete for ${ }^{125}$ I-IGF-I binding to MA-20 immobilized receptors ( $\mathrm{IC}_{50}$ values for competiton by IGF-I of $0.25 \mathrm{nM}$ and by insulin of $107 \mathrm{nM}$ ). As shown in Fig. 2, the percentage of insulin/IGF-I hybrid receptors was significantly higher in muscle from NIDDM patients compared to normal subjects (74.0 \pm 9.0 vs. $44.3 \pm 1.6 \%$, respectively, $P<0.0001)$. To further validate the microwell-based immunoassay, quantitation of hybrid receptors was assessed by precipitating receptors from muscle extracts with $\alpha$-IGF-IR-PA or MA-20 antibody, and immunoblotting with $\alpha$-IGF-IR-PA antibody. A representative Western blot is shown in Fig. 3, in which $\alpha$-IGFIR-PA and MA-20 antibody precipitate a single molecular species of approximately $M_{\mathrm{r}} 130,000 \mathrm{D}$, corresponding to the $\alpha$ subunit of the IGF-I receptor. Scanning densitometry was used to quantitate the levels of the $M_{\mathrm{r}} 130,000 \mathrm{D}$ protein precipitated by MA-20 antibody and immunoblotted with $\alpha$-IGF-IRPA antibody. Mean levels of hybrid receptors were 1.6-fold 

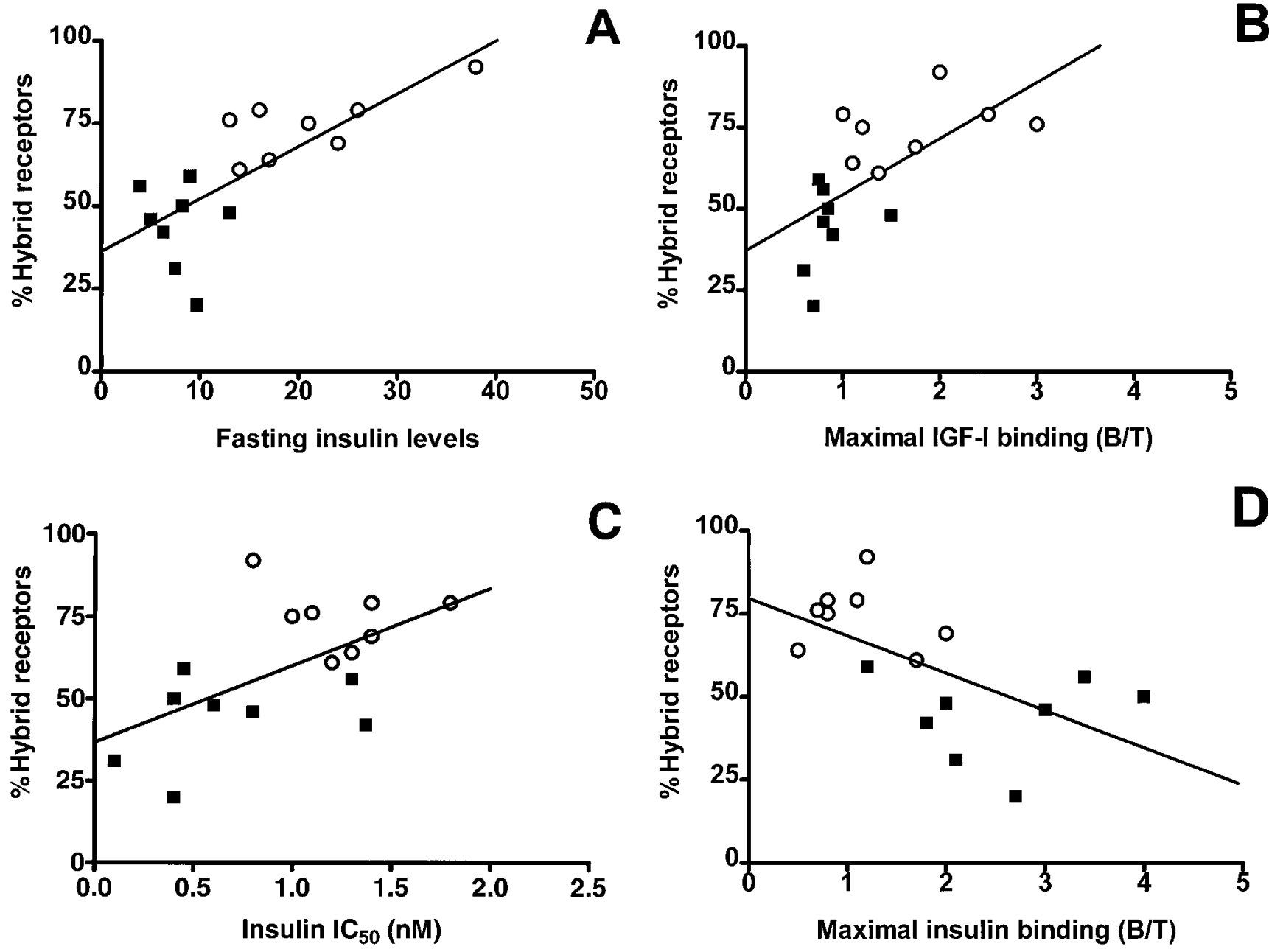

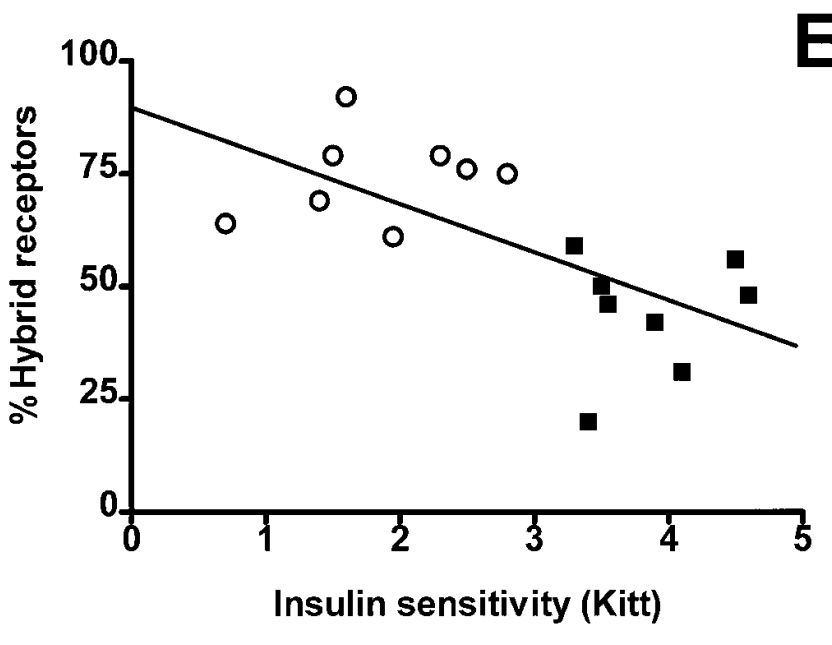

higher in NIDDM patients as compared with normal subjects $(P<0.001)$. These results were in close agreement with those obtained with the microwell-based immunoassay. The percentage of hybrid receptors was positively correlated with fasting insulin levels $(r=0.75 ; P<0.0008)$, with IGF-I receptor number $(r=0.63 ; P<0.008)$, and $\mathrm{IC}_{50}$ of insulin binding inhibition $(r=0.60 ; P<0.02)$, whereas the percentage was negatively correlated with insulin receptor number $(r=-0.60 ; P<0.01)$
Figure 4. Relative abundance of hybrid receptors in skeletal muscle from NIDDM patients (open symbols) and normal subjects (closed symbols) in relation to fasting insulin levels $(A)$, maximal IGF-I binding $(B), \mathrm{IC}_{50}$ of insulin binding inhibition $(C)$, maximal insulin binding $(D)$, and in vivo insulin sensitivity $\left(\mathrm{K}_{\mathrm{itt}}\right)(E)$.

and in vivo insulin sensitivity measured by ITT $(r=-0.7, P<$ 0.005; Fig. 4).

\section{Discussion}

The molecular mechanism(s) responsible for insulin resistance in NIDDM is still unclear. In the past $20 \mathrm{yr}$, investigators have extensively studied the role of insulin receptors in the patho- 
genesis of insulin resistance. Recently, it has become apparent that an insulin receptor $\alpha-\beta$-hemireceptor and an IGF-I receptor $\alpha-\beta$-hemireceptor assemble as hybrid receptors in cells and tissues expressing both receptors (7-14). A limited functional characterization of hybrid receptors has been performed in studies of cells overexpressing insulin receptors and with affinity-purified hybrid receptors (11-14). These studies indicate that hybrid receptors are functionally similar to type-I IGF receptors, rather than insulin receptors, with respect to hormone binding affinity, receptor autophosphorylation, ligand internalization, and degradation. Thus, the presence of hybrid receptors would be expected to affect insulin binding affinity and decrease insulin sensitivity in tissues expressing both receptors. It is possible that increased expression of hybrid receptors in target tissues of insulin action contributes to insulin resistance. In the present study, we have investigated the relative distribution of hybrid receptors in skeletal muscle of normal and NIDDM subjects. We have developed and applied a novel microwell-based immunoassay that is capable of quantitating the relative abundance of hybrid insulin/IGF-I receptors in small samples of human tissue. Quantitation of hybrid receptors revealed that the proportion of hybrids was significantly higher in skeletal muscle of NIDDM patients compared to normal subjects. The proportion of hybrid receptors was correlated with a decrease in both insulin binding affinity and in vivo insulin sensitivity measured by an insulin tolerance test. These data indicate that alterations in the relative abundance of insulin /IGF-I hybrid receptors in skeletal muscle may be associated with reduced insulin sensitivity in NIDDM patients. Thus far, there have been no reports of decreased insulin binding affinity in skeletal muscle of NIDDM patients $(23,24)$. The reason for this discrepancy is unclear, but it may be due to methodological differences. In the present study, measurements of insulin binding were performed with highly enriched immobilized insulin receptors, which include insulin holoreceptors and hybrid receptors. In contrast, in previous studies insulin binding assays were performed on partially purified lectin preparations which include insulin, hybrid, and type-1 IGF receptors. Thus, copurification of type-I IGF receptors with insulin receptors could explain the differences between our results and those of previous studies. Alternative explanations include contamination of muscle specimens by other tissues, differences in clinical characteristics of the subjects examined, or other confounding variables.

It is not known how the expression of insulin/IGF-I hybrid receptors is regulated. Hybrids are presumably formed in the endoplasmic reticulum by disulfide linkage of proreceptors at an early posttranslational step. Our results raise the possibility that increased expression of IGF-I receptors and/or decreased expression of insulin receptors could increase the number of hybrid receptors. Studies with transfected rodent cells expressing the human insulin receptor (14) or coexpressing both the insulin receptor and the IGF-I receptor (13) have led to similar conclusions. Taken together, these results suggest that the proportion of hybrid receptors in tissues expressing both receptors may be a function of the relative number of insulin and IGF-I receptors. The observed decrease in insulin receptor expression in NIDDM is consistent with previous studies showing a significant decrease in insulin binding to skeletal muscle of NIDDM patients and could be a consequence of elevated plasma insulin levels (23). In the current study, plasma insulin levels were significantly higher in NIDDM patients than in normal subjects, and were correlated with a decreased number of insulin receptors and an increased proportion in insulin/ IGF-I hybrid receptors. Alternative explanations are also possible. For example, alterations in muscle fiber type composition might explain the NIDDM-associated decreased expression of the insulin receptor and increased expression of hybrid receptors. It has been demonstrated in rats that insulin binding is higher in type I, slow twitch oxidative fibers than in type IIb, fast twitch glycolytic fibers (25). Therefore, lower levels of slow twitch oxidative fibers in NIDDM patients may result in a decreased number of insulin receptors and an increased number of hybrid receptors. However, this possibility seems unlikely because several previous studies in humans failed to detect differences in fiber type composition between normal and NIDDM subjects (26-28). It is worthy to note that the decrease in insulin-receptor expression in NIDDM does not reflect a generalized decrease in all muscle proteins, because IGF-I receptor's number was increased, and the estimated recovery of total muscle proteins did not differ between the two groups. Alternatively, increased expression of insulin/IGF-I hybrid receptors may represent a primary defect rather than a secondary event due to hyperinsulinemia. Further studies are required to address this issue.

Recombinant human IGF-I (rhIGF-I) has been proposed as a potential therapy for NIDDM (29-31). Preliminary studies have shown that treatment with rhIGF-I increases insulin sensitivity and improves glycemic control in NIDDM patients $(30,32)$. The mechanisms by which IGF-I exerts these effects in vivo are unclear as IGF-I can act through type-I IGF receptors, insulin receptors, or both. Our data raise the intriguing possibility that IGF-I might stimulate glucose transport and glycogen synthesis in muscle through insulin/IGF-I hybrid receptors. Therefore, increased expression of hybrid receptors that bind IGF-I with higher affinity than insulin may contribute to decrease insulin sensitivity, and increase sensitivity to rhIGF-I in NIDDM patients. Alternatively, rhIGF-I may enhance insulin sensitivity by downregulating type I IGF receptors thus decreasing insulin/IGF-I hybrid receptor content.

In summary, we developed a novel microwell-based immunoassy to assess the distribution of insulin/IGF-I hybrid receptors in human tissues. Using this method, we have provided the first direct evidence for increased expression of insulin/ IGF-I hybrid receptors in NIDDM patients as compared to normal subjects. Increased expression of hybrid receptors was correlated with a decrease in both insulin binding affinity and in vivo insulin sensitivity measured by insulin tolerance test. These results raise the possibility that alterations in expression of hybrid receptors may contribute, at least in part, to insulin resistance, a major component of NIDDM.

\section{Acknowledgments}

We are grateful to Prof. Renato Lauro (Rome, Italy) for his advice and helpful discussions.

This work was supported in part by grants from Consiglio Nazionale delle Ricerche No. 95.00908.PF41 (G. Sesti) and Ministero dell'Università e della Ricerca Scientifica e Tecnologica (G. Sesti).

\section{References}

1. De Fronzo, R.A. 1988. The triumvirate: $\beta$-cell, muscle, liver: a collusion responsible for NIDDM. Diabetes. 37:667-687.

2. De Fronzo, R.A., R. Gunnarsson, O. Bjorkman, M. Olsson, and J. 
Wahren. 1985. Effects of insulin on peripheral and splanchnic glucose metabolism in noninsulin dependent (type II) diabetes mellitus. J. Clin. Invest. 76: 149-155.

3. Cheatham, B., and C.R. Kahn. 1995. Insulin action and the insulin signaling network. Endocr. Rev. 16:117-142.

4. Ullrich, A., R.J. Bell, E.Y. Chen, R. Herrera, L.M. Petruzzelli, T.J. Dull, A. Gray, L. Coussens, Y.C. Liao, M. Tsubokawa, et al. 1985. Human insulin receptor and its relationship to the tyrosine kinase family of oncogenes. Nature (Lond.). 313:756-761.

5. Ebina, Y., L. Ellis, K. Jarnagin, M. Edery, L. Graf, E. Clauser, J.H. Ou, F. Masiarz, Y.W. Kan, I.D. Goldfine, et al. 1985. The structural basis for hormoneactivated transmembrane signalling. Cell. 40:747-758.

6. Ullrich, A., A. Gray, A.W. Tam, T. Yang-Feng, M. Tsubokawa, C. Collins, W. Henzel, T. Le Bon, S. Kathuria, E. Chen, S. Jacobs, et al. 1986. Insulinlike growth factor I receptor primary structure: comparision with insulin receptor suggests structural determinants that define functional specificity. EMBO J. 5:2503-2512.

7. Soos, M.A., and K. Siddle. 1989. Immunological relationships between receptors for insulin and insulin-like growth factor-I. Biochem. J. 263:553-563.

8. Moxham, C.P., V. Duronio, and S. Jacobs. 1989. Insulin-like growth factor-I receptors $\beta$-subunit heterogeneity. J. Biol. Chem. 264:13238-13244.

9. Soos, M.A., J. Whittaker, R. Lammers, A. Ullrich, and K. Siddle. 1990. Receptor for insulin and insulin-like growth factor-I can form hybrid dimers. Biochem. J. 270:383-390.

10. Treadway, J.L., B.D. Morrison, I.D. Goldfine, and J.E. Pessin. 1989. Assembly of insulin/insulin-like growth factor-I hybrid receptors in vitro. J. Biol. Chem. 264:21450-21453.

11. Soos, M.A., C.E. Field, and K. Siddle. 1993. Purified hybrid insulin/insulin-like growth factor-I receptors bind insulin-like growth factor-I, but not insulin, with high affinity. Biochem. J. 290:419-426.

12. Langlois, W.J., T. Sasaoka, C.C. Yip, and J.M. Olefsky. 1995. Functional characterization of hybrid receptors composed of a truncated insulin receptor and wild type insulin-like growth factor 1 or insulin receptor. Endocrinology. 136:1978-1986.

13. Frattali, A.L., and J.E. Pessin. 1993. Relationship between $\alpha$ subunit ligand occupancy and $\beta$ subunit autophosphorylation in insulin/insulin-like growth factor-I hybrid receptors. J. Biol. Chem. 268:7393-7400.

14. Seely, B.L., D.R. Reichart, Y. Takata, C.C. Yip, and J.M. Olefsky. 1995. A functional assessment of insulin/Insulin-like Growth Factor-I hybrid receptors. Endocrinology. 136:1635-1641.

15. National Diabetes Data Group. 1979. Classification and diagnosis of diabetes mellitus and other categories of glucose intolerance. Diabetes. 28:10391057.

16. Bonora, E., P. Moghetti, C. Zancanaro, M. Cigolini, M. Querena, V. Cacciatori, A. Corgnati, and M. Muggeo. 1989. Estimates of in vivo insulin action in man: comparision of insulin tolerance tests with euglycemic and hyperglycemic glucose clamp studies. J. Clin. Endocrinol. Metab. 68:374-378.

17. Sesti, G., R. D'Alfonso, M.D. Vargas Punti, L. Frittitta, V. Trischitta, Y.Y.Liu, P. Borboni, R. Longhi, A. Montemurro, and R. Lauro. 1995. Peptidebased radioimmunoassay for the two isoforms of the human insulin receptor. Diabetologia. 38:445-453.

18. Forsayeth, J.R., A. Montemurro, B.A. Maddux, R. De Pirro, and I.D. Goldfine. 1987. Effect of monoclonal antibodies on human insulin receptor au- tophosphorylation, negative cooperativity, and down-regulation. J. Biol. Chem. 262:4134-4140.

19. Benzi, L., V. Pezzino, P. Marchetti, D. Gullo, P. Cecchetti, A. Masoni, R. Vigneri, and R. Navalesi. 1986. A- $14{ }^{125}$ I monoiodoinsulin purified by different high-performance liquid chromatographic procedures and by polyacrylamide gel electrophoresis: preparation, immunochemical properties and receptor binding affinity. J. Chromatogr. 378:337-347.

20. Bradford, M.M. 1978. A rapid and sensitive method for the quantitation of microgram quantities of protein utilizing the principle of protein-dye binding. Anal. Biochem. 72:248-254.

21. Scatchard, G. 1949. The attraction of proteins for small molecules and ions. Ann. NY Acad. Sci. 51:660-675.

22. Rosenzweig, S.A., C. Zetterstrom, and A. Benjamin. 1990. Identification of retinal insulin receptor using site-specific antibodies to a carboxyl-terminal peptide of the human insulin receptor $\alpha$-subunit. J. Biol. Chem. 265:1803018034

23. Caro, J.F., M.K. Shina, S.M. Raju, O. Ittoop, W. J. Pories, E.G. Flickinger, D. Meelheim, and G.L. Dohm. 1987. Insulin receptor kinase in human skeletal muscle from obese subjects with and without noninsulin dependent diabetes. J. Clin. Invest. 79:1330-1337.

24. Arner, P., T. Pollare, H. Lithell, and J.N. Livingston. 1987. Defective insulin receptor tyrosine kinase in human skeletal muscle in obesity and type 2 (non-insulin-dependent) diabetes mellitus. Diabetologia. 30:437-440.

25. James, D.E., A. Zorzano, M. Boni-Schnetzler, R.A. Nemenoff, A. Powers, P.F. Pilch, and N.B. Ruderman. 1986. Intrinsic differences of insulin receptor kinase activity in red and white muscle. J. Biol. Chem. 261:14939-14944.

26. Obermaier-Kusser, B., M.F. White, D.E. Pongratz, Z. Su, B. Ermel, C. Munhlbacher, and H.U. Haring. 1989. A defective intramolecular autoactivation cascade may cause the reduced kinase activity of the skeletal muscle insulin receptor from patients with non-insulin-dependent diabetes mellitus. J. Biol. Chem. 264:9497-9504.

27. Garvey, W.T., L. Maianu, J.A. Hancock, A.M. Golichowski, and A. Baron. 1992. Gene expression of GLUT4 in skeletal muscle from insulin-resistant patients with obesity, IGT, GDM, and NIDDM. Diabetes. 41:465-475.

28. Andersen, P.H., S. Lund, H. Vestergaard, S. Junker, B.B. Kahn, and O. Pedersen. 1993. Expression of the major insulin regulatable glucose transporter (GLUT4) in skeletal muscle of noninsulin-dependent diabetic patients and healthy subjects before and after insulin infusion. J. Clin. Endocrinol. Metab. 77:27-32.

29. Kolaczynski, J.M., and J.F. Caro. 1994. Insulin-like growth factor-I therapy in diabetes: physiological basis, clinical benefits, and risks. Ann. Int. Med. 120:47-55.

30. Zenobi, P.D., S.E. Jaeggi-Groisman, W.F. Riesen, M.E. Roder, and E.R. Froesch. 1992. Insulin-like growth factor-I improves glucose and lipid metabolism in type 2 diabetes. J. Clin. Invest. 90:2234-2241.

31. Hussain, M.A., O Schmitz, A. Mengel, A. Keller, J.S. Christiansen, J. Zapf, and E.R. Froesch. 1993. Insulin-like growth factor-I stimulates lipid oxidation, reduces protein oxidation, and enhances insulin sensitivity in humans. $J$. Clin. Invest. 92:2249-2256.

32. Moses, A.C., S.C.J. Young, L.A. Morrow, M. O'Brien, and D.R. Clemmons. 1996. Recombinant human insulin-like-growth factor I increases insulin sensitivity and improves glycemic control in type II diabetes. Diabetes. 45:91-100. 